Conclusions ASM cells express a number of PRMTs at mRNA and protein levels. PRMT1 associates with a number of chemokine and cytokine promoters after TNF- $\alpha$ stimulation. PRMTs may have an important role in regulating chemokine production from ASM cells in asthma, and are a promising target for future investigations in asthma.

\section{P237 LUNG FUNCTION DECLINE IS ASSOCIATED WITH SERUM PERIOSTIN LEVEL BUT NOT FRACTIONAL EXHALED NITRIC OXIDE OR BLOOD EOSINOPHILS IN SEVERE ASTHMA}

AH Mansur, V Mitchell, J Sullivan, K O'Shea, L White. Heart of England NHS Trust, Birmingham, West Midlands

\subsection{6/thoraxjnl-2016-209333.380}

Background In the airways, periostin encoded by the POSTN gene is up-regulated by IL13-IL4-TGF- $\beta$ axis. It is produced by structural cells such as epithelial cells and fibroblasts and inflammatory cells such as eosinophils and macrophages. Consequently it has been linked to airways remodelling, mucus production and subepithelial fibrosis. However, an association between periostin and lung function impairment in severe asthma has not been confirmed.

Methods Unselected patients attending severe asthma centre were clinically characterised using systematic protocol and undergone lung functions, serum periostin, fraction exhaled nitric oxide (FeNO) and peripheral blood eosinophils (PBE) measurement. Correlation analysis and one way analysis of variance were undertaken to explore the relationships.

Results 127 patients consented to the study (mean age 45.5 yrs [range 17-70], 88 [69\%] females), 72/103 (69\%) were atopic. The mean FEV1 was 2 L, mean\%predicted FEV1 68.1, and mean FEV1/FVC ratio was 71.3. The mean inhaled daily corticosteroids dose was $1.65 \mathrm{mg} /$ day and $56.3 \%$ were on maintenance oral corticosteroids. Periostin measurement was available in 78 patients who had a mean level of $49.5 \mathrm{ng} / \mathrm{L}(\mathrm{SD} \pm 18.1)$. Using $50 \mathrm{ng} / \mathrm{L}$ as a cut-off point, $30 / 78(36 \%)$ patients had high periostin and 48/78 (62\%) had low periostin. The mean FEV1 in the periostin high group was $1.69 \mathrm{~L}$ Compared to $2.15 \mathrm{~L}$ in the low group ( $p=0.018$ ) (see Figure). We also observed significant correlation between serum periostin and $\%$ predicted FEV1 $(\mathrm{r}=0.36, \mathrm{p}=0.0017)$. In contrast the association analysis between FeNO and PBE with FEV1 were both non-significant ( $\mathrm{p}=0.8$ and $\mathrm{p}=0.35$ respectively).

Conclusion Raised serum periostin is associated with low lung function in this cohort of severe asthma but not FeNO or BPE. Further research is required to confirm this relation and explore the role of periostin as predictor of decline in lung function and airway remodelling.

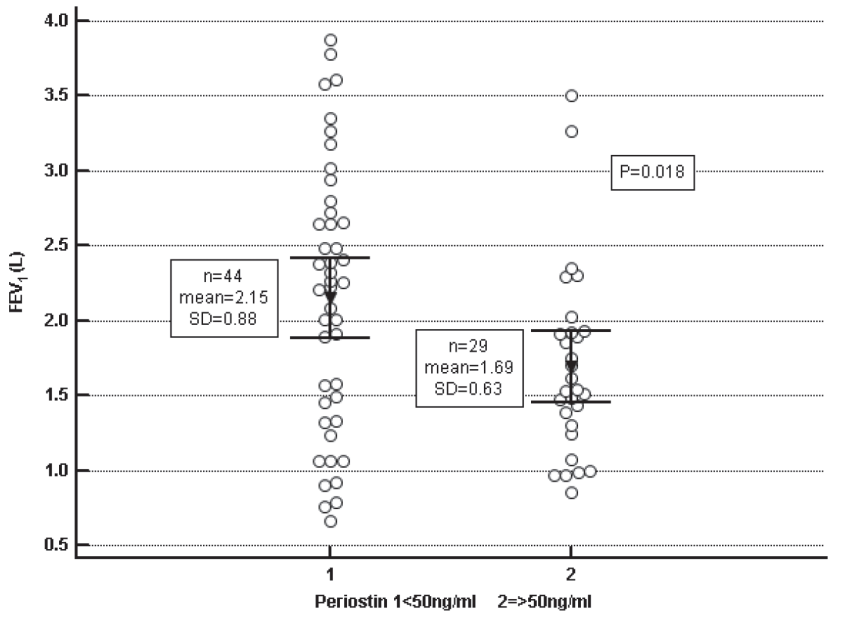

Abstract P237 Figure 1 Periostin and FEV1

\section{P238 INVESTIGATING GENOME WIDE DNA METHYLATION IN AIRWAY SMOOTH MUSCLE CELLS FROM ASTHMATIC AND NON-ASTHMATIC DONORS}

${ }^{1} \mathrm{RL}$ Clifford, ${ }^{1} \mathrm{JK}$ Patel, ${ }^{1} \mathrm{DE}$ Shaw, ${ }^{1} \mathrm{AJ}$ Knox, ${ }^{2} \mathrm{MS}$ Kobor. ${ }^{1}$ Division of Respiratory Medicine and Nottingham Respiratory Research Unit, University of Nottingham, Nottingham, UK; ${ }^{2}$ Centre for Molecular Medicine and Therapeutics, Child and Family Research Institute, Vancouver, Canada

\subsection{6/thoraxjnl-2016-209333.381}

Rationale Genetic mechanisms fail to fully explain asthma pathogenesis and environmental factors are considered to play an important role. Environmental factors may lead to permanent changes in epigenetic patterns and contribute to asthma. Epigenetics is the study of heritable changes in gene expression that are not due to changes in DNA sequence. DNA methylation is a reversible modification of DNA structure in which a methyl group is added to cytosine residues. Parental smoking affects the methylation of buccal cell DNA from children and children with early onset wheeze have an altered blood DNA methylation profile to healthy individuals. No studies have compared DNA methylation profiles in the disease relevant cell type of airway smooth muscle (ASM) cells.

Methods DNA was isolated from ASM cells at passage 5 and bisulphite treated to convert epigenetic information into sequence-based information. Site specific, quantitative genome wide methylation was determined using the Illumina 450K Infinium Methylation BeadChip array. Hits were validated by Pyrosequencing. RNA was extracted simultaneously for mRNA expression analysis by real time PCR.

Results There were no independent $\mathrm{CpG}$ sites associated with asthmatic status of ASM cells following multiple test correction. Without correction over $13000 \mathrm{CpG}$ sites showed a significant difference in methylation (linear modelling, $p$ value $>0.05$ ) 